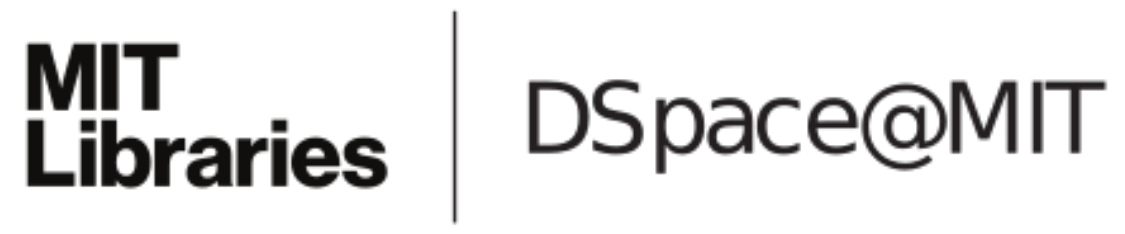

MIT Open Access Articles

\author{
Out of the Bread Box: Eleanor Melville \\ Metcalf and the Melville Legacy
}

The MIT Faculty has made this article openly available. Please share how this access benefits you. Your story matters.

Citation: Kelley, Wyn. "Out of the Bread Box: Eleanor Melville Metcalf and the Melville Legacy." Leviathan 13, no. 1 (March 2011): 21-33.

As Published: http://dx.doi.org/10.1111/j.1750-1849.2010.01451.x

Publisher: Wiley Blackwell

Persistent URL: http://hdl.handle.net/1721.1/86119

Version: Author's final manuscript: final author's manuscript post peer review, without publisher's formatting or copy editing

Terms of Use: Article is made available in accordance with the publisher's policy and may be subject to US copyright law. Please refer to the publisher's site for terms of use. 


\section{Out of the Bread Box: Eleanor Melville Metcalf and the Melville Legacy Wyn Kelley}

Late-twentieth-century digital archives of canonical authors have produced uncommonly expansive texts. Whereas once editors had to squeeze a book, with notes, glossaries, bibliographies, lists of variants, illustrations, critical introductions - a clanking hulk of editorial apparatus - between two cloth-covered boards, new media paradigms can create and sustain inconceivably immense bodies of work. ${ }^{i}$ With dazzling multimedia components, open-ended collaborations between readers connected by wikis and discussion forums, and armies of young scholars eager to play, the digital literary archive seems to represent the very latest, most promising, least contained, and in all ways biggest thing around. Yet as older media forms - print, film, video, sound recordingsevolve in new media landscapes, they have met (and collided) in what Henry Jenkins has identified as a "convergence culture," where users may access these many forms through one portal. This utopian notion of a single "Black Box" suggests that, like Hamlet, one can be bounded in a technological nutshell and count oneself a king of infinite digital space. Whatever one's "Box"- - a laptop, cellphone, or other personal device — one can use it to travel freely within a "participatory culture" where people and texts migrate, merge, mix, and re-mix in endlessly proliferating combinations (Jenkins 1-24). And although in Convergence Culture Jenkins points to the "Black Box Fallacy" as an unachievable dream of the communications industry, it has remarkable staying power, as entrepreneurs search for the one device that can do and contain all.

How very different from this Box of infinite space seems the tin bread box within which Elizabeth Shaw Melville stored her husband's manuscript pages of Billy Budd and 
which Eleanor Melville Metcalf shared with Melville's first biographers and critics. We tend to think of Melville's family as having preserved his writings within a metaphorically as well as literally constrictive box. Protective of his reputation, they controlled access to his papers for a considerable time after his death and were viewed by the academic establishment as having stifled Melville, his work, and his legacy. The Melville Revival might be read as signifying the triumph of critics who wanted to liberate Melville from the box where his family had entombed him. We should remember, however, that Eleanor Melville Metcalf was the one to take Melville out of the box, not wholly relinquishing his work to writers like Raymond Weaver, Lewis Mumford, and Charles Olson but in fact editing his personal papers in ways that made them available, indeed literary, to later scholars. Although her work has not been sufficiently appreciated, Metcalf's editorial choices have proven unexpectedly vital in a new media environment.

On October 14, 1951, Minna Littmann, staff writer at the New Bedford StandardTimes, produced a substantial two-page Sunday spread on Eleanor Melville Metcalf's gift to Harvard University of precious letters, manuscripts, and objects from the Melville family. Littmann's relationship with Metcalf dated back over two decades to August, 1929, when Littmann had written in loving detail about Metcalf's summer house in Edgartown, Massachusetts, a dwelling formerly owned by Valentine Pease, captain of Melville's first whaling ship the Acushnet. ${ }^{\text {ii }}$ The 1929 article was written eight years after Raymond Weaver's biography of Melville, and in the same year as Lewis Mumford's, 
both of which had effusively acknowledged the importance of Metcalf's contributions to Melville biography. But at that early stage of the Melville Revival and of Metcalf's life (1882-1964), Littmann dwelt primarily on Melville's relationship with Valentine Pease, Metcalf's personal memories of her grandfather, and the historical coincidences circulating through the Edgartown house.

In 1951, returning to the family she had covered twenty-two years before, Littmann gave far more emphasis to Metcalf's work as keeper of the Melville flame, which by then was burning brightly. Referring to the legend surrounding Weaver's discovery of the Billy Budd manuscript, she titled her article, "Priceless Melville Papers Preserved in Bread Box.” The story showed a far greater awareness of Melville's literary reputation than her first, which began by speaking of him simply as "the author of Moby Dick" [sic]. By 1951 one could summarize, as Littmann did in a sentence, the common understanding of Melville's nineteenth-century career: "Like many another genius, Melville, author of the world famed novel 'Moby Dick,' [sic] and other novels, died scantily rewarded or appreciated for work into which he poured his soul." In the midtwentieth century, however, "his literary greatness is being acknowledged by spoken and published praise, research, works of art inspired by his writings, and republication of his books." Littmann echoed the by-then universal judgment that Moby-Dick was an American epic and Melville an American tragic hero.

If the Littmann of 1951 makes Melville a figure larger-than-life, she presents Metcalf as an industrious handmaiden, focusing on the "satisfaction" Metcalf feels in her task as "unofficial literary executor" of her grandfather's reputation. This work begins symbolically with preserving the bread box, which Metcalf describes to her interviewer: 
Grandmother kept his papers in a tin box. Among them was the manuscript of "Billy Budd," his last work. The box passed to my mother's unmarried sister, Elizabeth, when grandmother died. Mother gave it to me in 1919, since I was the member of the family most interested in Melville's work. I had browsed in it from time to time through the years, but never looked through it systematically. When it came to me, I was too busy with my young sons to go through it. But I realized it was valuable.

The bread box seems emblematic of the humble and domestic beginnings of Melville's twentieth-century career: "The tin box handed down by her grandmother with the Melville papers," says Littmann, "still is in Mrs. Metcalf's possession. . . . The box, she confided, was really a bread box, not a strong box." The idea of the bread box as unprepossessing, feminine domestic object (not a "strong box," a masculine treasure chest) seems to indicate by how lucky a chance Melville's reputation had been discovered and saved by scholars and critics. Two years later in her own Herman Melville: Cycle and Epicycle, Metcalf likewise emphasized the modest character of the box: "The famous so-called 'trunk' (in reality a bread box), in which my grandmother had kept unpublished manuscripts, came to my father's house in South Orange, to be stored most of the time in the attic. I would get it out now and then, look through the contents, read here and there, utterly ignorant but fascinated" (262). Even though Metcalf overcame her ignorance to inspire an entire generation of Melville scholars, she expressed to Littmann her sense of unfitness for the role: "I gave the papers to Harvard because I didn't want the responsibility of taking care of them." 
Such attitudes seem unnecessarily modest now, even quaint in a time when every scrap of Melville's writing is cherished and in which Metcalf's concern for her grandfather's literary reputation has guaranteed its survival, as well as the careers of numerous scholars. But we have new reasons to be grateful for her work, new ways to appreciate Metcalf's contributions to Melville scholarship. Metcalf's editing and criticism of his writings anticipate emerging modes of criticism in a rapidly changing communications environment. ${ }^{\text {iii }}$ To state the obvious, changes in the way we now read, share, and disseminate texts have weighty implications for criticism as traditionally practiced. Indeed textual criticism of the kind nurtured by the heirs of the Melville Revival is dead. But that development has shown itself to be profoundly invigorating for scholars working in a new-media context. Metcalf's critical methods, once scorned as sub-scholarly, "merely" biographical, blindly partisan, feminine, or simply not critical at all, now appear deeply valuable as we explore texts and methods of editing that once seemed beneath the notice of academic scholarship.

Unfortunately, for many scholars born after the Melville Revival, it may seem strange to think of Eleanor Melville Metcalf as a critic at all, since she has been appreciated far more for her service to Melville biography than anything else. ${ }^{\text {iv }}$ Her contributions, however, to the study of Melville's writings should be seen as remarkably prescient to scholars in an age of digital texts and text editing. It is time to recognize her early role in preparing the ground for study of what John Bryant has called the Melville Text: namely, a body of writing informed and enlarged by digital tools and resources and a sense of authorship as extending beyond print editions to more fluid and various ones. ${ }^{\mathrm{v}}$ I have argued elsewhere, in speaking of Melville's sister Augusta as proto-editor of the 
unpublished Melville family letters, that a traditional bias in favor of print texts and canonical work has obscured the importance of such acts of selection, cataloguing, annotation, and preservation as Melville's sisters, wife, and daughters performed (“Literary Thirst”). Eleanor Melville Metcalf's editing went far beyond these basic skills, and her work has had a vital impact on Melville scholarship throughout the almostcentury since she began it.

Yet Eleanor Melville Metcalf's reputation steadily declined after her death in 1964. At first, Melville's biographers had warmly praised her critical acumen. Raymond Weaver thanked her for alerting him to a wide range of materials: "manuscripts, letters, journals, annotated books, photographs .... But she did far more. My indebtedness to Mrs. Metcalf's vivid interest, her shrewd insight, her keen sympathy can be stated only in superlatives" (vii). Lewis Mumford too offered "hearty thanks . . . [to Mrs. Metcalf] for giving me the benefit of her own memories and family tradition, as well as her courtesy and hospitality in placing at my disposal Melville's manuscripts" (v). He also recognized her leading role in the Weaver biography: "through Mrs. Metcalf, [Weaver] discovered Melville's unpublished manuscripts and included them in a definitive edition of his work" (v). Perhaps not all could say with Charles Olson that the Metcalfs "indeed have made me a member of their family" (40). But we have long known that Metcalf shaped the version of Melville celebrated during the long Revival: a "man of genius," as she and others almost universally described him, but one who also pursued his career within "an intimate social scene" (Cycle xvi) to which she had privileged access.

Recent biographers have taken a more jaundiced view of what some have seen as Metcalf's shaping of the Melville myth. Especially as scholars have probed Melville's 
marriage and family life, some have questioned Metcalf's role in spreading what appears to be incriminating and misleading information. Hershel Parker in particular debunks stories that came to Eleanor via her disaffected mother, Frances Melville Thomas, and that she shared with Charles Olson: "One of Melville's great-grandsons reported a rumor passed on to him by the poet Charles Olson, supposedly derived from Eleanor Metcalf, Melville's oldest granddaughter, that Melville had pushed his wife down the stairs. Olson is not a source a responsible biographer can put much faith in, and in any case the stories that came down in the family were often skewed. Eleanor was the source for most of the domestic anecdotes that scholars have heard, and, although she gained some information from Sam Shaw and others, her own main source was her mother, Frances" (628). Parker notes that Frances's stories got passed along and freely disseminated whereas those of Charlotte Hoadley, Melville's quieter, less bitter, and perhaps more observant niece, did not (933). It is a wise caution, and we have Parker to thank for the first recent reconsiderations of any kind about Metcalf's contributions, but it proceeds from a skeptical view of those who knew and studied Melville closely and maintains the persistent opinion of Metcalf as family secretary rather than independent observer, textual editor, and scholar-critic.

For Andrew Delbanco, interestingly, the issue of family mythmaking and Eleanor Melville Metcalf's role in it comes up in relation to Melville's purportedly autobiographical novel Pierre and underlines the difficulties of separating fact from fiction in Melville's work and biography. Quoting Eleanor in Herman Melville: Cycle and Epicycle, Delbanco points to a central problem many biographers have grappled with: "Here [was] a sick man writing of some matters known to be true, some entirely 
untrue, combined in such a way that the family feared its members and their friends might assume all to be true." Having identified one of the most sensational matters in Melville's life and oeuvre (the possibility of illegitimate birth and incest in the family) and forthrightly calling him "sick" in the process, Metcalf went on to ask, "would others be able to separate fact from invention?" (Cycle 135; qtd Delbanco180). This perceptive question suggests the ways Melville's family struggled to separate reality and myth but also gestures toward the ranks of biographers who have struggled with the same problem. When they do so, they often associate Metcalf with the mythmaking and, whether positively or negatively, assume that she could not view her grandfather or his work with an objective and critical eye.

Metcalf has thus suffered from being identified primarily with the biographical and often sensational side of Melville studies. But we have been distracted by these stories long enough. Metcalf should more properly be viewed as a farsighted editor of Melville's unpublished writings, someone who recognized as writings texts that had never seen daylight before, and by doing so enabled new forms of textual criticism. Her two publications - an edition of Melville's 1849 travel diary, the Journal of a Visit to London and the Continent (1948), and her family narrative in letters, Herman Melville: Cycle and Epicycle (1953) — showcase learned, sensitive, and imaginative editing of texts that in her time were considered inconsequential — a travel diary, family letters, and marginalia - but that under her expert hand have survived. Her editing has made them literary in ways that her contemporaries could not have envisioned and that communicate to an age in which such supposedly nonliterary texts have found more appreciative readers. 
We might return to the tin bread box as a useful symbol of this rereading of Metcalf's work. The bread box seems fitly to represent the Melville women's primary task: preservation. But it suggests another function as well: editing. For in organizing his texts, the Melville women began the long process of editing them for posterity, as his sister Augusta did when she saved family letters, collecting, cataloguing, and arranging them before they can be read, as editors must do. The family members have been criticized by legions of frustrated Melville scholars for burning letters and documents that would be valuable in the future. But their acts of selection and rejection might argue for editorial concerns, not simply a mass familial cover-up. In this task, Eleanor, the first to publish the family's editorial work, proved herself deeply resourceful and innovative.

And from an early age. Her grandmother Elizabeth Shaw Melville, though herself well-educated and deeply involved with Melville's career, could not do more in later years than actively encourage the efforts of early editors and biographers like J.E.A.

Smith, Titus Munson Coan, and Arthur Stedman. ${ }^{\text {vi }}$ But she did recognize and nurture her granddaughter's strong literary inclinations and her interest in Melville: “My [Eleanor's] interest in all the associations that gave my grandmother pleasure were [sic] an added happiness to her" (Cycle 290). When Eleanor was still in her mid-teens, Lizzie wrote to an old school friend, the popular author Adeline Whitney, to introduce her granddaughters. A long and affectionate correspondence between Mrs. Whitney and Eleanor ensued until the older woman's death and seems to have inspired Metcalf in her literary career (Metcalf Papers). Metcalf"s remark to Minna Littmann that she "was the member of the family most interested in Melville's work" may have appeared to other 
family members a presumptuous boast, but Lizzie seems to have recognized Eleanor's gifts while she was still in her teens. ${ }^{\text {vii }}$

Metcalf's first venture, interestingly, was not as family biographer but as textual editor. Her copious notes to Melville's European Journal reveal a mind as limber as it is patient and learned Even if she consulted with scholars about the contents of her annotations, they show a depth of knowledge, reading, and insight that comes from deep familiarity with the texts. A note on Melville's purchase of Thomas Chatterton's poems, for example, richly details Melville's markings and marginalia (152). Another on a Rembrandt portrait speculates on which of two possible such portraits in the National Gallery Melville would have preferred and why (151). Her discussion of Melville's acquisition of Thomas Hope's Anastasius connects it knowledgeably with Moby-Dick and with questions about Islam and Ramadan (142-3). ${ }^{\text {viii }}$ And her personal touches are insightful as well. In glossing the phrase "glorious chop," she comments on Melville's "succulent appreciation of good food" and connects it with his buying a cookbook for his wife (116). ${ }^{\text {ix }}$ She remembers that Melville loved eating figs (131) and that Lizzie was fond of the word "pesky" (147). Metcalf”s reviewers_-Luther S. Mansfield, Charles Anderson, Granville Hicks - in general praised her thoroughness but found the journal nonliterary and failed to credit her ingenuity in making it as literary as indeed she did. To readers now, however, her work seems a superb example of an editor's power to expand the meaning and richness of a text. As Melville's works get annotated in hypertext editions, Metcalf's appetite for annotation and marginalia and her drawing on a diverse array of sources and intertexts seem farsighted and discerning. ${ }^{\mathrm{x}}$ 
Metcalf's second published work, Herman Melville: Cycle and Epicycle, takes up more centrally the task of intervening in the scholarly field that had grown up around Melville by 1953. Although she presents her work modestly as that of a mostly-silent arranger of family documents, her voice is artful and critical. Her greatest contribution may be the realistic narrative she makes out of the contents of the family's bread box: namely, of a working writer, a man within an active, diverse, and multi-talented family, a human being and not a myth. Biographers and critics would not adopt this view of Melville's life and work until later in the twentieth century. ${ }^{\text {xi }}$ Yet Metcalf's seemingly unassuming attempt to capture Melville through the family letters offered more psychological depth and critical judgment than could be conveyed even with similar methods in Jay Leyda's $\log$. It also provided a realistic assessment of his writing; gave more weight to his later career, including the poetry, than earlier biographers had done; and stripped away the aura of tragic genius, with its unfortunate connotations of nationalism, racism, and sexism. She corrected the masculinist biases of early biographers to render the family's women, especially Melville's wife and sisters, more sympathetically, ${ }^{\text {xii }}$ and she showed what Melville owed to his broader social context, avoiding the heavy-handed psychoanalysis of critics like Henry A. Murray. Her book reads now as an insightful portrait of a complex human being and author, and although she steps aside to let the letters tell most of the story, she arrays her materials skillfully, making a strong case for the power and significance of her narrative.

"I will let the 'clan' tell its story" (259), Metcalf asserts, but in fact she tells much of it herself, including rich information from her own research and experience. Her account merits more sustained attention than I can offer here, but it is worth noting the 
places where she intervenes critically to question the family's mythmaking. In one such example, she considers Melville's love of music, which "seems never to have been fully satisfied” (76). Reflecting on her mother Frances's stories of unsuccessful piano lessons or of Melville's monotonously rhythmic recitations of Clarel, Metcalf seems to reach into the family bread box only to retrieve a few minor crumbs. But then: "There is a vague, haunting memory I have of a guitar with a blue ribbon that he was anxious to have her [Frances] learn to play. Whether she ever learned a few chords I do not know; the guitar vanished, and the memory fades. If I had read Pierre early in life, I might have had an incentive to ask questions about Isabel's guitar" (77). Metcalf reveals a certain longing for and a perception of what might have been concealed within the family's vaults, as well as in Melville's mind. Then she asserts a bracing judgment of her mother's memories in her conclusion: "she [Frances] could be at times half right and half wrong. As when I put the question to her, 'Was he interested in music?' She simply said, 'Liked it but did not know anything about it, no special interest.' The facts seem to belie part of this at least" (77).

If passages like these led her first readers to think Metcalf derived only domestic anecdotes from her connection with the family, the book nevertheless demonstrates the critical importance of female networks in producing new scholarship. Metcalf's opening acknowledgments, after a general nod to "the conversations and correspondence I have enjoyed over a period of thirty-odd years," move immediately to her greatest find: "a most important new letter of Sophia Hawthorne's to her mother about Melville” (vii), a letter that she later calls "the most important and perceptive letter any of his contemporaries wrote about Melville - with the exception, one must assume, of a certain 
letter of Hawthorne's written a year later" (91). Before acknowledging the many Melville scholars with whom she conversed and corresponded over those thirty-odd years, Metcalf thanks Hawthorne's granddaughter Beatrix Hawthorne Smyth, as well as Louise Hall Tharp (her connection to Smyth), and her own second cousins Agnes, Helen, and Margaret Morewood, women who directly supplied the materials of her account. Throughout the book, although she assumes a deferential role in relation to Melville and the scholars who pursued him, she maintains a keen critical edge and a lively spirit, balancing intimate family details with knowledgeable assessments of his writing.

Outside of her published work, one of Metcalf's less well-known but still promising contributions to Melville scholarship lies in the area of his multicultural sources. In a note to the European Journal, for example, she speculates on a cryptic jotting: "Indian (Gay-Head) Sweetheart flogged" (170). Her gloss shows that she interviewed a Mrs. Anna Hayson of Gay Head to find out more about Native American folklore. The note only broaches the subject, but in a speech to the Melville Society at Williams College in 1951, she focused on her research into the phrase and into Native American legends of a white whale. She argued that Melville's interest in Indians and their spiritual traditions was central to his life and work and urged scholars to pursue it. ${ }^{\text {xiii }}$ In the 1953 Herman Melville: Cycle and Epicycle she made the same observation more unobtrusively: "Past the gates of Eden, past the wandering, a fabulous White Whale, it may be out of aboriginal Indian myth, was so to stir the depths of his being that language came to life with passion" (33).

In the 1951 interview with Minna Littmann, Metcalf placed emphasis on another area of study that she considered promising and, up to that point, neglected: "I think ... 
someone might find it rewarding to make a study of Melville and the fine arts. He had a very real and keen interest in art, and collected lovely things." Fortunately Robert K. Wallace and Elizabeth Schultz, among others, have devoted themselves to this study with outstanding results. ${ }^{\text {xiv }}$

Metcalf seems most immediately contemporary in her appreciation of multimedia adaptations and remixings of Melville texts. In Cycle and Epicycle she speaks happily of "the use of material from Moby Dick [sic] and Billy Budd by musicians, playwrights, and scenario writers, with adaptations for radio and television" (295). She relished the Classics Illustrated comic book versions of Moby-Dick and Typee and displayed them proudly to Minna Littmann. She boasted to Littmann "of at least one youth who was stimulated by the lurid pictures and balloon texts to read Melville in the original version," thus anticipating some of the pedagogy that we now consider cutting-edge. Although she told Littmann that she did not like the John Barrymore film versions of Moby-Dick, she greatly admired the paintings of Gil Wilson, Miguel Covarrubias, and Boardman Robinson and was well-versed in musical works based on Moby-Dick and Billy Budd. ${ }^{\mathrm{xv}}$ Her devotion to Melville's belongings also led to her reading his texts in light of favorite objects, like his pipes, or beloved prints like "Satan Exalted Sat," as well as reading these treasures in light of his writing. ${ }^{x v i}$ Such an embrace of objects as texts seems fresh and deeply relevant to us now.

It may appear obvious to us that Metcalf's work as editor was associated in her day with the female domestic labor implied in making bread and keeping it in a tin box. Her efforts to promote the family's interests by keeping the Melville myth alive have 
almost invariably been read through a sexist lens that diminishes preservation in favor of more seemingly adventurous and critical forms of scholarship. Metcalf, herself a respected poet, negotiated these gender barriers with some difficulty. ${ }^{\text {xvii }}$ Minna Littmann's interview preserves the view of Metcalf as "unofficial literary executor" of her grandfather's reputation. Metcalf did not herself challenge this idea. The image of the dutiful granddaughter naturally accorded with the gender expectations of her day.

But the newspaper's reporting unwittingly reveals the more complex dimensions of this gender stereotyping and opens up the implications of Metcalf's collecting and preservation in terms we now appreciate as pertaining to new digital media. Across the page from Littmann's article in the New Bedford Standard-Times is a remarkable piece about another female collector and preserver of historic artifacts: Mrs. Harry Hull of Middleboro, who "has been busy for the last seven years collecting buttons. At present she has approximately 2,500 buttons of all sizes, materials, colors and descriptions." The author of this article, Kay Blair, calls attention to the sheer size of the collection but also to its diversity and methodology: "she has her buttons carefully segregated into novel classifications. There are glass, wood, and metal buttons and buttons with animals, birds, insects, and flowers stamped or painted on them. ... The buttons of each group have been carefully mounted on 9 inch by 12 inch cardboards which in turn have been bound together into loose leaf folios or framed in glass-enclosed trays." As important as the buttons themselves is the woman who collected them and the meanings she assigns. Mrs. Hull sees her work as representing the large community of people who share her love of objects that fasten shirts and people together: "she says, the monetary value of [the buttons] is insignificant compared to the friendships formed and cemented while 
exchanging them. They offer a source of real enjoyment in arranging them, studying their materials and gaining a knowledge of history, music, geography and art through them."

This double-page Sunday spread proudly features women collectors and scholars and the women writers who admire them. It also presents a model of scholarship that resembles the sharing of resources online, the fan practices that Henry Jenkins has identified as generating what he calls the new media literacies and participatory culture of the digital age. ${ }^{\text {xviii }}$ In 1951, Mrs. Hull and Mrs. Metcalf were being appreciated not for keeping their materials in a figurative bread box but for taking them out, arranging them skillfully so that a wide spectrum of readers would appreciate them and draw conclusions of their own. In liberating Melville from the strong box of traditional modes of criticism, Eleanor Melville Metcalf freed him from older media forms, older methods of collecting and disseminating information and opinion. We work now in a media environment that can value her scholarly enterprise as being inherently critical, creative, and generative of new insights. 


\section{WORKS CITED}

Anderson, Charles. "Review" [untitled]. American Literature 21.2 (May, 1949): 250-51. Bryant, John. “The Melville Text.” In A Companion to Herman Melville. Ed. Wyn Kelley. Oxford: Blackwell Publishing, 2006. 553-66.

Delbanco, Andrew. Melville: His World and Work. New York: Knopf, 2005.

Hicks, Granville. "Melville's Log of a Visit to Europe.” New York Times (Dec. 26, 1948).

Jenkins, Henry. Convergence Culture: Where Old and New Media Collide. New York: New York University Press, 2008.

Kelley, Wyn. “'My Literary Thirst': Augusta Melville and the Melville Family Correspondence.” Resources in American Literature 25.1 (January 2000): 46-56.

Littmann, Minna A. “Edgartown Finds New Link with Melville: Author's Daughter Learns She is Living in Former Home of Captain in Moby Dick.” New Bedford Sunday Standard (August 11, 1929).

“Priceless Melville Papers Preserved in Bread Box.” New Bedford Standard-Times (October 14, 1951).

Mansfield, Luther S. "Review" [untitled]. Modern Language Notes 65.4 (Apr. 1950): 285-6.

Melville, Herman. Journal of a Visit to London and the Continent, 1849-1850. Ed. Eleanor Melville Metcalf. Cambridge: Harvard University Press, 1948.

Metcalf, Eleanor Melville. Herman Melville: Cycle and Epicycle. Cambridge: Harvard University Press, 1953.

Mumford, Lewis. Herman Melville. New York: Harcourt Brace, 1929. 
Olson, Charles. Call Me Ishmael: A Study of Melville. San Francisco: City Lights Books, 1947.

Parker, Hershel. Herman Melville: A Biography. Volume 2, 1851-1891. Baltimore: Johns Hopkins University Press, 2002.

Weaver, Raymond M. Herman Melville: Mariner and Mystic. New York: George H. Doran, 1921.

\footnotetext{
${ }^{\mathrm{i}}$ The most established American studies digital archives include The Walt Whitman Archive (Ed Folsom and Kenneth M. Price, eds., http://www.whitmanarchive.org/); the Dickinson Electronic Archives (Martha Nell Smith, et. al., eds., http://www.emilydickinson.org/); Mark Twain in His Times (Stephen Railton, ed., http://etext.virginia.edu/railton/); and Uncle Tom's Cabin \& American Culture (Stephen Railton, ed., http://utc.iath.virginia.edu/). John Bryant has commenced the Melville Electronic Library (MEL) with funding from the National Endowment for the Humanities.

${ }^{\text {ii }}$ Littmann's two newspaper articles do not include page numbers. They are collected in the Eleanor Melville Metcalf Papers (Call Number A/M 58) at the Arthur and Elizabeth Schlesinger Library, Radcliffe Institute for Advanced Study. My thanks to Dennis Marnon of the Houghton Library at Harvard University for guiding me through this collection. Hershel Parker mentions Littmann's 1929 article in his Herman Melville: A Biography, 2:794-5 and 915.

${ }^{\text {iii }}$ My thinking about traditional and new media has been shaped by the work of the Project New Media Literacies research group in the Comparative Media Studies Program at MIT, as laid out in their White Paper ("Confronting the Challenges of Participatory Culture: Media Education for the $21^{\text {st }}$ Century" at http://newmedialiteracies.org/) and in The New Media Literacies Teachers' Strategy Guide: Reading in a Participatory Culture
} 
also available at the New Media Literacies website. I am particularly indebted to Henry Jenkins and Jenna McWilliams for their ideas and support.

${ }^{\text {iv }}$ One person who does not seem to share this view is Dennis C. Marnon of the Houghton Library at Harvard University. I am deeply grateful to him for sharing his knowledge of Eleanor Melville Metcalf and for his generous gifts of advice and time.

"See also Wyn Kelley, “Writ in Water': The Books of Moby-Dick” forthcoming in Alfred Bendixen, ed., A Companion to the American Novel (Oxford: Blackwell Publishing).

${ }^{v i}$ See Merton M. Sealts, Jr., The Early Lives of Melville: Nineteenth-Century Biographical Sketches and Their Authors (Madison: University of Wisconsin Press, 1974).

${ }^{\text {vii }}$ Hershel Parker records Charlotte Hoadley's frustration with the negative stories about the Melvilles, "which struck her as slurring Melville's parents out of a taste for 'notoriety.' She [Charlotte] recalled that Raymond Weaver in his biography had called Allan and Maria Melvill "'monsters" and made various slurring remarks concerning them,' and assumed that Weaver's impression was conveyed and authorized by either Frances Thomas (now dead) or Eleanor" (900).

viii For a deeper understanding Melville's interest in Islam, see Timothy Marr, The Cultural Roots of American Islamicism (New York: Cambridge University Press, 2006).

${ }^{\text {ix }}$ For a fuller discussion of the cookbook, see Wyn Kelley, "'I'm Housewife Here': Melville and Domestic Economy." Melville Society Extracts 98 (September 1994): 7-10. ${ }^{x}$ See Steven Olson-Smith, ed., Melville's Marginalia Online (Boise State University, 2005-); October 22, 2009. Haskell Springer's online edition of "Bartleby, the Scrivener" (at http://raven.cc.ukans.edu/ zeke/bartleby/) seems to be no longer available, but he discusses the project in his online essay, "A Web 'Bartleby' for Teachers, Students, and Scholars" (http://english.ttu.edu/KAIROS/6.1/coverweb/springer/index.html). See also examples of annotated texts at the University of Virginia site: David Padilla, ed., Herman Melville's Billy Budd: The Hypertext; and Scott Eric Atkins, ed., The Confidence-Man Hypertext (American Studies @ The University of Virginia, Hypertexts, 1994-). October 22, 2009.

${ }^{\mathrm{xi}}$ See especially Laurie Robertson-Lorant, Melville: A Biography (New York: Clarkson Potter, 1998).

${ }^{x i i}$ For example, she calls the much-neglected Augusta "one of the most sympathetic and understanding persons who were in a position to know Melville well" (Cycle 93).

xiii "Speech of Welcome" at meeting of the Melville Society, Williams College, September 2, 1951. Typescript. In the Eleanor Melville Metcalf Papers.

${ }^{\text {xiv }}$ See especially Robert K. Wallace, Melville and Turner: Spheres of Love and Fright (Athens: University of Georgia Press, 1992); Frank Stella's Moby-Dick (Ann Arbor: University of Michigan Press, 2000); and Elizabeth Schultz, Unpainted to the Last: Moby-Dick and Twentieth-Century American Art (Lawrence: University Press of Kansas, 1995).

${ }^{x v}$ See Elizabeth Schultz, "Creating Icons: Melville in Visual Media and Popular Culture," in Wyn Kelley, ed., A Companion to Herman Melville (Oxford: Blackwell Publishing, 2006), 532-52. 
${ }^{x v i}$ In Cycle and Epicycle, Metcalf speaks of the family's love of his varied canes and pipes (216). On "Satan Exalted Sat," see her letter to Henry A. Murray, June 12, 1948. In the Eleanor Melville Metcalf Papers.

xvii See Eleanor Melville Metcalf, Poems (Cambridge: Eleanor Melville Metcalf, 1946).

xviii In addition to the publications noted above, see also Henry Jenkins' blog, "Confessions of an Aca-Fan," http://www.henryjenkins.org/. 